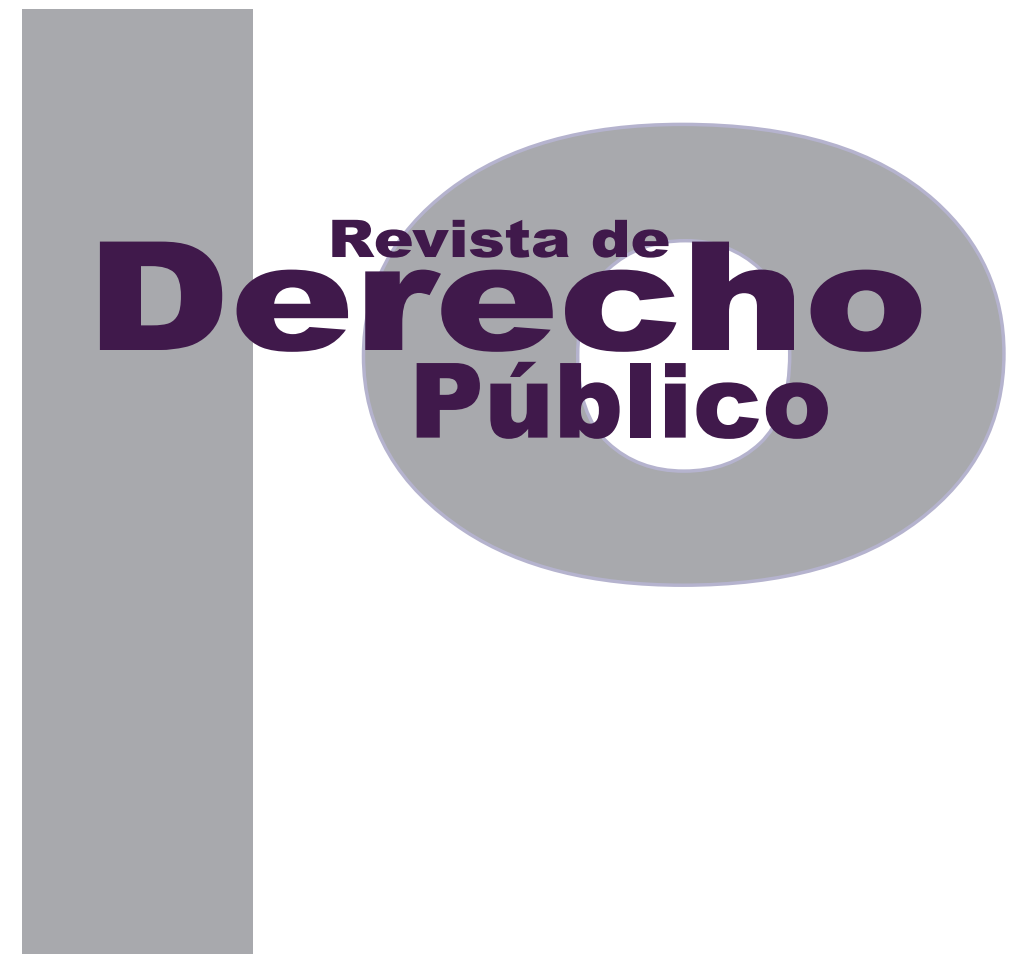

\title{
Global FINANCIAL STANDARDS AND NETWORKS: the Global AdMinistrative LAW Perspective
}

\author{
MAURIZIA De Bellis
}

Universidad de los Andes

Facultad de Derecho

Revista de Derecho Público N. ${ }^{\circ} 30$

Enero - Junio de 2013. ISSN 1909-7778 


\title{
Global Financial Standards and Networks: the Global Administrative Law Perspective
}

\author{
Maurizia De Bellis*
}

\begin{abstract}
RESUMEN
Diferentes tipos de autoridades forman parte en la arquitectura financiera global: internacionales, transnacionales y nacionales; públicas y privadas. El Consejo de Estabilidad Financiera (FBS por sus siglas en inglés), fortalecido en 2009, tiene por objeto coordinar el trabajo de estos organismos. Sin embargo, no todos los actores cumplen las mismas funciones: el G20 tiene por objeto establecer la agenda de reforma y dar el respaldo político a organismos técnicos; el FMI y el BM que, a través de FSAP y ROSCs, tienen el objetivo de hacer cumplir las normas, y no de crearlas. El proceso de elaboración de normas, incluso después de la crisis, todavía está en manos de las redes transnacionales. Sin embargo, el FSB está el mismo encargado de crear normas, contrario a sus predecesores.

El Derecho Administrativo Global (GAL), como enfoque de investigación, es especialmente adecuado para enmarcar el análisis de los es-
\end{abstract}

Different types of authorities take part in the global financial architecture: international, transnational and national; public and private. The FSB, strengthened in 2009, aims at coordinating the work of all these bodies. Yet, not all these actors play the same functions: the G20 aims at setting the agenda of reform and gives its political endorsement to technical bodies; the IMF and the World Bank, through the FSAP and Roscs, work as standard enforcers, not as standard setters. The standard setting process itself is still, even after the crisis, in the hands of transnational networks. Moreover, the FSB itself is, contrary to its predecessor, also a standard setter.

The Global Administrative Law (GAL) research approach is particularly well-suited to frame global financial standards: because of the features of the standard setters; because of the object of regulation; because of the standard setting procedures; because of ways standards are 
tándares globales financieros: debido a las características de los órganos normativos, al objeto de regulación, a los procedimientos de elaboración de normas y a la forma en que éstas son implementadas. En particular, los principios y procedimientos que provienen del derecho administrativo nacional se han utilizado con el fin de fomentar la rendición de cuentas de los actores que crean normas. Sin embargo, algunos ejemplos - como el borrador de Basilea II, en el que fueron usados ampliamente procedimientos de notificación y comentarios, que resultaron en la creación de un riesgo de captura regulatoria - muestran que los instrumentos GAL deben ser elaborados a la medida, con el fin de garantizar la representación equilibrada de todos los intereses en juego. De lo contrario, su posible efecto positivo, tanto en la responsabilidad de los reguladores globales como en la eficacia de la regulación, se verá afectada.

Palabras Clave: Derecho administrativo global, normas internacionales, regulación global, G20, FSB, Basel Committee implemented. In particular, principles and procedures coming from national administrative law traditions have been used in order to foster the accountability of the standard setters. Yet, some examples -such as the drafting of Basel II, where extensive notice and comment procedures were used, resulting in a risk of regulatory capture- show that GAL instruments need to be attentively tailored, in order to guarantee the balanced representation of all the interests at stake. Otherwise, their potential positive effect on both the accountability of global regulators and the efficacy of regulation is impaired.

KEY WORDS: global administrative law, international standards, global regulation, G20, FSB, Basel Committee 


\section{SUMARIO}

Introduction - I. THE GLOBAL FINANCIAL ARCHITECTURE - A. The G7, the G20, the IMF and the World Bank - B. A "Network of Networks": the Financial Stability Board (FSB) - C. The Transnational Regulatory Networks (TRNs): the BCBS and the IOSCO - D. The Private Organizations: the IASB and the IFAC - E. Summing Up - II. THE STANDARDS AND THE STANDARD-SETTING PROCEDURE - A. The 12 'Key' Standards of the FSB Compendium - B. The Basel Capital Accord - C. The IOSCO Code of Conduct Fundamentals for Credit Rating Agencies - D. The FSB Recommendations - E. Summing Up - III. THE IMPLEMENTATION: BETWEEN HARD AND SOFT LAW - A. The Incorporation in Binding Acts - B. The Financial Sector Assessment Program (FSAP) and the Reports on the Observance of Standards and Codes (ROSCS) - C. The Peer Reviews - D. Summing Up - IV. CONCLUDING REMARKS - Bibliography. 
Introduction

Global financial standards, principles and guidelines are not a new phenomenon. The G10 central banks governors set up the Basel Committee on Banking Supervision (BCBS) in 1974, in the aftermath of the Bankhaus Herstatt collapse, and it started setting the first standards on banking at the end of the decade ${ }^{1}$. Yet, it is in the late 90s that the phenomenon gains momentum. The G7 starts supporting the standard setting process within the всвS and its counterpart for securities, the International Organization for Securities Commissioners (IOSco), not to mention the private standard setter for accounting, the then named International Accounting Standards Committee (IASC; in 2001, it has been reorganized and renamed International Accounting Standard Board (IASB)). At the same time, the group of seven aimed at fostering the standards dissemination process, involving the International Monetary Fund (IMF) and the World Bank in this attempt.

The spread of global financial standard has long been considered a successful trend. Transnational regulatory networks (TRNS) in particular, such as the BCBS and the IOsco, which are at the heart of the process, were regarded as an architrave of the New World Order ${ }^{2}$. Critiques were grounded on the secrecy of these networks and their technocratic nature ${ }^{3}$. Others argued oth-

1 Ethan B. Kapstein, Governing the Global Economy. International Finance and the State, 1994.

2 Anne-Marie Slaughter, A New World Order, 2004, p. 224.

3 Martin Shapiro, "Deliberative', 'Independent' Technocracy v. Democratic Politics: Will the Globe Echo the EU?", in Law \& Contemporary erwise, showing that the growing transparency and due process followed by the networks were effective means in strengthening their accountability ${ }^{4}$.

In the aftermath of the global financial crisis, both the effectiveness of the standards as a regulatory tool ${ }^{5}$ and the efficiency of the networks as a preferential forum for cooperation ${ }^{6}$ have been questioned. The due process the global regulators were following was not regarded any more as an instrument to achieve better accountability, but as one of the reasons leading to the "regulatory capture", which helps explaining the failure of some of the global standards ${ }^{7}$.

The phenomenon of global financial standards has been examined from a number of perspectives. Some have emphasised the role the IMF and the World Bank play within a new "international financial architecture" ${ }^{8}$. Others have looked at the infrastructure of global financial regulation, arguing that the substance of global

Problems, 2005, Vol. 68, n. 3-4, p. 342 ss. and Sol Picciotto, "Networks in International Economic Integration: Fragmented States and the Dilemmas of Neo-Liberalism", in Northwestern Journal of International Law \& Business, Vol. 17, n. 2/3, 1997, p. 1014 ss.

4 Michael S. Barr and Geoffrey P. Miller, "Global Administrative Law: the View from Basel”, in European Journal of International Law, Vol. 17, n. 1,2006 , p. 15 ss.

5 Layna Mosley, "An End to Global Standards and Codes?", in Global Governance, 2009, Vol. 15, p. 1 ss.

6 David Zaring, "International Institutional Performance in Time of Crisis", in Chicago Journal of International Law, 2010, Vol. 10, p. 475 ss.

7 Daniel Tarullo, Banking on Basel. The Future of International Financial Regulation, Washington D.C., Peterson Institute, 2008, p. 104 ss.

8 See Ngaire Woods, The Globalizers. The IMF, the World Bank, and Their Borrowers, Ithaca, Cornell University Press, 2006, and D.D. Bradlow and D.B. Hunter (eds.), International Institutions and International Law, Alphen - The Netherlands, Wolters Kluwer, 2010. 
financial regulation is often shaped by private entities ${ }^{9}$. Lastly, as mentioned above, transgovernmental networks have often been identified as a successful new model of governance ${ }^{10}$.

The Global Administrative Law (GAL) research approach is particularly well-suited to frame global financial standards ${ }^{11}$ : because of the features of the standard setters; because of the object of regulation; because of the standard setting procedures; because of ways standards are implemented.

First, GAL scholars identified five main models of global administrations: administration by formal international organizations; administration based on collective action by transnational networks of governmental officials; distributed administration; hybrid intergovernmental/private administration and administration by pri-

9 Among the first ones, Timothy Sinclair, "The Infrastructure of Global Governance: Quasi-Regulatory Mechanisms and the New Global Finance", in Global Governance, 2001, vol. 7, p. 441 ss. For a recent analysis, Tim Buthe e Walter Mattli, The New Global Rulers. The Privatization of Regulation in the World Economy, Princeton e Oxford, Princeton University Press, 2011.

10 Anne-Marie Slaughter, "The Real New World Order", in Foreign Affairs, 1997, Vol. 76, n. 5, p. 184 ss.

11 Among the first sets of papers about global administrative law there are three journal symposia: Benedict Kingsbury et al. (eds.), "The Emergence of Global Administrative Law", in Law and Contemporary Problems, 2005, Vol. 68, p. 1-385; Benedict Kingsbury and Nico Krisch (eds.), "Global Governance and Global Administrative Law in the International Legal Order", in European Journal of International Law, 2006, Vol. 17, p. 1-278; and the "Global Administrative Law symposium", in New York University Journal of International Law and Politics, 2005, Vol. 37. Subsequent publications include sets of papers from conferences convened by the New York University School of Law Institute for International Law and Justice's (IILJ) and partner institutions: a substantial series of working papers and extensive bibliographies as well as links to papers from other scholars around the world can be found on the website <www.iilj.org/GAL> and <http://www.irpa.eu/ index.asp?idA=161>. See also Sabino Cassese et al. (eds.), Global Administrative Law: Cases, Materials, Issues, IRPA-IILJ, third edition, 2012, available at SSRN: http://ssrn.com/abstract=2140384. vate institutions with regulatory functions ${ }^{12}$. In global financial governance, regulators which fall within each of these models can be found. Intergovernmental international organizations, such as the IMF and the World Bank, intervene in the implementation of financial standards. Transnational regulatory networks such as BCBS and Iosco develop rules for banking and securities. The IASB and the International Federation of Accountants' (IFAC), which set accounting and auditing standards, are examples of private global governance. The Financial Stability Board (FSB), which brings together not only the intergovernmental international organizations and the transgovernmental regulatory networks mentioned above, but also domestic regulators, is a case of hybrid administration.

Second, the content of financial standards and rules is of an administrative nature. The emergence of problems that exceed domestic regulatory capacity - such as financial stability-drives a displacement of regulatory decisions from domestic authorities to transnational networks ${ }^{13}$.

Third, both transnational and private regulators are increasingly setting their standards following procedures which try to apply principles well known within domestic administrative law ${ }^{14}$.

12 See Benedict Kingsbury et al., "The Emergence of Global Administrative Law", in Law \& Contemporary Problems, 2005, Vol. 68, p. 15 ss., at $20-23$.

13 Richard Stewart, "Administrative Law in 21st century", in New York Law Review, 2003, Vol. 78, p. 437 ss.

14 See Sabino Cassese, "A Global Due Process of Law", in Anthony Gordon et. al. (eds.), Values in Global Administrative Law, Oxford, Hart Publishing, 2011, p. 17 ss., and Giacinto della Cananea, "Beyond the State: the Europeanization and Globalization of Procedural Administrative Law", in European Public Law, 2003, p. 563 ss; Armin von Bogdandy, "Legitimacy of International Economic Governance: Interpretative 
Fourth, the implementation of global standards requires a conceptual framework significantly different from the tradition international law model, based on the ratification of international treaties ${ }^{15}$. Global standard are first established as voluntary. In the last years, though, a number of different mechanisms -ranging from incorporation in binding acts to peer reviews- have been put in place in order to foster compliance with global standards.

The analysis shows that, even though a number of different types of bodies take part in financial governance, standard setting still takes place essentially within networks, with the significant exception of standards for accounting, put in place by the IASB. The paper argues that the GAL approach is well-equipped for fostering the accountability of standard setters at different levels: during the standard setting process and during the implementation phase.

The paper will provide, first, an overview of the different bodies intervening in global financial regulation (Section II). Second, it will examine some examples of global standards, taking into account both their content and the standard setting process (Section III). Third, it will look at the implementation of global standards, and more specifically at their tendency to "make a transi-

Approaches to WTO law and the Prospects of its Proceduralization", in Stefan Griller (ed.), International Economic Governance and Non-Economic Concerns - New Challenges for the International Legal Order, Wien-New York, Springer, 2003, p. 128 ss.

15 See Benedict Kingsbury et al., "Global Governance as Administration - National and Transnational Approaches to Global Administrative Law", in Law \& Contemporary Problems, 2005, Vol. 68, n. 3-4, p. 1 ss., at 3; and Richard Stewart, "U.S. Administrative Law: a Model for Global Administrative Law?”, in Law \& Contemporary Problems, 2005, Vol. 68, n. $3-4$, p. 63 ss., at 69 . tion from soft to hard law"16 (Section IV). Lastly, it will look at the accountability regimes of the regulators, which appear to profit steadily of the GaL perspective (Section V).

\section{THE GLOBAL FINANCIAL ARCHITECTURE}

The different bodies intervening in global financial governance are traceable to the different types of global administration analyzed within GAL literature.

\section{A. The G7, the G20, the IMF and the World Bank}

The G7's involvement in the setting of global financial standards dates back to the $90 \mathrm{~s}$. In the Lyon summit, the group of seven recognized the standard setters' activity and urged the IMF and the World Bank to foster the implementation of the standards ${ }^{17}$. The International Financial Institutions (IFI) role in the process is more the one of standard enforcers than the one of standard setters, as it will be shown (Section IV).

The G7's influence on the shaping of the global financial architecture increased in the late 90s, in the aftermath of the Asian financial crisis ${ }^{18}$.

16 See Robert P. Delonis, "International Financial Standards and Codes: Mandatory Regulation Without Representation", in New York University Journal of International Law \& Politics, 2004, Vol. 36, p. 563 ss.

17 G7, Economic Communiqué: Making a Success of Globalization for the Benefit of All, 28 June 1996, in http://www.g7.utoronto.ca/ summit/1996lyon/communique.html. For a comment on such evolution, see W. Murden, "Banking Supervision and Government Policy: the Role of Regulators in International Financial Reform", in Fordham Finance, Securities and Tax Law Forum, 1999, Vol. 4, p. 35 ss. 
The reforms approved at the time were based on the establishment of two new institutions ${ }^{19}$. The G20 brings together emerging countries and G10 ones ${ }^{20}$. Even though regarded since its inception as a step forward in the direction of more inclusiveness and representation ${ }^{21}$, until 2008 it met only as a group of financial ministers. When first established, the Financial Stability Forum (FSF) brought together, on the one hand, banking, securities and insurance transnational regulators (BCBS, IOSCO and IAIS, respectively), and intergovernmental international organizations (the IMF, the World Bank, the OECD and the Financial Action Task Force on Money Laundering (FATF)), and, on the other hand, national authorities from the G7 countries and from Australia, The Netherlands, Hong Kong and Singapore ${ }^{22}$.

After 2008, due to the spread of the global financial crisis, the role of both institutions has been strengthened. The first G20 political summit took place in Washington, in November 2008. The G20 aims at establishing itself as

national financial architecture was particularly frequent: see, ex multis, B. Eichengreen, Toward a New Financial Architecture. A Practical PostAsia Agenda, Washington D. C.: Institute for International Economics, 1999.

19 See Communiqué of G-7 Finance Ministers and Central Bank Governors, 20 February 1999, available at http://www.g7.utoronto.ca/finance/ fm022099.htm.

20 Emerging countries such as Argentina, Brazil, China, India, Indonesia, Korea, México, Russia, Saudi Arabia, South Africa and Turkey.

21 In this sense, see Randall D. Germain, "Global Financial Governance and the Problem of Inclusion", in Global Governance, 2001, vol. 7, p. 411 ss

22 Also the Bank for International Settlements (BIS) together with its committees (the Committee on Payment and Settlement Systems (CPSS) and the Committee on the Global Financial System (CGFS)), and the ECB took part in the Forum. "the premier forum for international economic cooperation"23.

\section{B. A "Network of Networks": the Finan- cial Stability Board (FSB)}

After the global financial crisis, the FSF was reorganized as FSB, its membership was broadened ${ }^{24}$ and its mandate and powers clearly identified within the FSB Charter $^{25}$, recently revised ${ }^{26}$. In the FSB participate -together with the international organizations and transnational networks, already members of the FSF- national administrative authorities (such as central banks, supervisory authorities and treasury departments) from the G20 countries. Hence, the FSB brings together and connects one to the other national, transnational and international authorities. Given that some of its members, such as the BCBS and the Iosco, are themselves transgovernmental networks, it can be defined as a "network of networks". Contrary to the transgovernmental networks, though, its member are not homogeneous in their structure, but they are very diverse.

According to the Charter, the main tasks included in the FSB mandate are: a) assessing the vul-

23 G20, Leaders' Statement, Pittsburgh, 23-4 September 2009, available at http://www.g20.org/Documents/pittsburgh_summit_leaders_statement 250909.pdf, para. 19.

24

The FSB has been established after the G20 London Summit in April 2009 and its membership has been broadened to all G20 countries regulatory authorities: see Fsb, Press Release, Financial Stability Forum re-established as the Financial Stability Board, 2 April 2009, available at http://www.financialstabilityboard.org/press/pr_090402b.pdf.

FSB, Financial Stability Board Charter, September 2009, available at http://www.financialstabilityboard.org/publications/r_090925d.pdf

26 FSB, Financial Stability Board Charter, June 2012, available at http:// www.financialstabilityboard.org/publications/r_120809.pdf. 
nerabilities affecting the global financial system and identifying related actions needed to address them, and their outcomes; (b) promoting coordination and information exchange among authorities responsible for financial stability; (c) monitoring market developments; (d) monitoring best practice in meeting regulatory standards; (e) undertaking joint strategic reviews of the policy development work of the international standard setting bodies to ensure their work is timely, coordinated, focused on priorities and addressing gaps ${ }^{27}$. Moreover, the FSB the FSB should develop its own standards and principles in areas which do not fall within the functional domain of another international standard setting body, or on issues that have cross sectoral implications ${ }^{28}$.

The FSB's main functions are four: it coordinates the activity of the standard setting bodies; it identifies priorities and actions to be taken under this regard; it publishes its own recommendations and standards: Section III); it monitors the implementation of the standards through peer reviews (Section IV).

Notwithstanding its limits (such as the scarce resources and the lack of binding powers), in the last years the Board played a crucial role, working as a link between the G20 and the standard setting bodies, prioritizing the reforms, establishing directly some relevant standards and trying to establish new tools to foster the implementation of standards (Section III and IV).

27

FSB, Charter, art. 2, para. 1.

28

FSB, Charter, art. 2, para. 3.
The recognition of the Board's standard setting function and its efforts in the establishment of new tools intended to foster compliance with the standards are particularly significant and show that the linkage between networks and standards does not result weakened, after the crisis.

Notwithstanding some proposals intended to set up an international financial organization or a new administrative body with binding powers $^{29}$, the standard setting activity still takes place within networks, and even more so, since the FSF -the predecessor of the FSB- did not execute a standard setting function.

\section{The Transnational Regulatory Net- works (TRNS): the BCBS and the IOSCO}

According to Anne-Marie Slaughter, TRNS are "patterns of regular and purposive relations among like government units working across the borders that divide countries from one another" ${ }^{30}$. They are "transgovernmental" because they "involve specialized domestic officials directly interacting with each other, often with minimal

29 For a critical point of view, see Douglas W. Arner and Michael W. TayIor, "The Global Financial Crisis and the Financial Stability Board: Hardening the Soft Law of International Financial Regulation?", 2009, AlIFL Working Paper No. 6, available at http://ssrn.com/abstract=1427084, and Eric J. Pan, "Challenge of International Cooperation and Institutional Design in Financial Supervision: Beyond Transgovernmental Networks", in Chicago Journal Of International Law, 2010, Vol. 11, p. 244 ss.

See Anne-Marie Slaughter, A New World Order, cit., at 14. See also David Zaring, "International Law by Other Means: The Twilight Existence of International Financial Regulatory Organizations", in Texas International Law Journal, 1998,Vol. 33, n. 2, p. 281 ss. e Id., "Informal Procedure, Hard and Soft, in International Administration", in The University of Chicago International Law Journal, 2005, Vol. 5, available at http://ssrn.com/abstract=692764. Among the most recent contributions on the subject, see Pierre-Hughes Verdier, "Transnational Regulatory Networks and Their Limits", in Yale Journal of International Law, 2009, Vol. 34, p. 113 ss. and Michael J. Warning, Transnational Public Governance. Networks, Law and Legitimacy, New York, Palgrave, 2009. 
supervision by foreign ministries" ${ }^{31}$. The concept of "network" is widespread in legal and political science literature, referring to a model of cooperation highly informal, loosely-structured, which does not take place through than negotiation.

The BCBS and the $10 s c 0$ are two leading examples of TRNS.

Established in 1974 by the G10 central bank governors, the BCBS is probably the most powerful and well known transgovernmental regulatory network ${ }^{32}$. Its membership has been broadened in the aftermath of the global financial crisis to include representatives from the G20 countries ${ }^{33}$.

Also the origins of the 10 sco date back to 1974 , when the Interamerican Association of Securities Commissions was established ${ }^{34}$. In 1983, this association was transformed in a universal network. The structure of the Iosco are set forth in its by laws (which are not accessible to the public).

The two networks have long been contrasted for two reasons. First, as the 10 sco is open to any do-

31 See Kal Raustiala, "The Architecture of International Cooperation: Transgovernmental Networks and the Future of International Law", in Virginia Journal of International Law, 2002, Vol. 43, n. 1, p. 1 ss., at 4-5.

32 About BCBS's history, structure and activity, see Duncan R. Wood, Governing Global Banking. The Basel Committee and the Politics of Financial Globalization, Aldershot, Ashgate Publishing, 2005.

33 Central bank governors and heads of supervision from Argentina, Indonesia, Saudi Arabia, South Africa and Turkey, together with Hong Kong and Singapore are now members of the Committee: see BCBS, Basel Committee Broadens its Membership, Press Release, 10 June 2009, http://www.bis.org/press/p090610.htm.

34

About IOSCO, see A.A. Sommer Jr., "losco: its Mission and Achievement", in Northwestern Journal of International Law \& Business, 1996 - 1997, Vol. 17, p. 15 ss. mestic securities regulator, while the BCBS membership is closed, some commentators concluded that "Basle is an example of leadership; Iosco is an example of democracy" ${ }^{35}$. Second, the всвS has long been considered to be the most powerful TRN, the Iosco being the weaker one ${ }^{36}$.

\section{The Private Organizations: the IASB and the IFAC}

The International Accounting Standards Board (IASB) is an international organization made up of private entities, which establishes standards and guidelines for the accounting sector. Founded on 2001, it is the successor of the International Accounting Standards Committee (IASC), created in 1973 in London $^{37}$. The objectives of the IASB are: to develop, in the public interest, a single set of high quality, understandable and enforceable global accounting standards; to promote the use and rigorous application of those standards; to bring about convergence of national accounting standards and international accounting standards ${ }^{38}$. Accounting standards established until 2001, by the IASC, are named International Accounting Standards (IAS), while standards produced by IASB after that date have

35 See John Braithwaite and Peter P. Drahos, Global Business Regulation, Cambridge, Cambridge University Press, 2000, at 156.

36

Daid Zaring, Peer Review As a Metric of Success For Regulatory Networks, Paper presented at the V GAL Seminar, Viterbo, 12-3 giugno 2009, available at http://www.irpa.eu/wp-content/uploads/2011/06/81. pdf, at 4 .

37 For a general overview of the IASB, see Walter Mattli and Tim Buthe, "Global Private Governance: Lessons from a National Model of Setting Standards in Accounting", in Law \& Contemporary Problems, 2005, Vol. 68 , n. 3-4, p. 225 ss.

38 See IFRS Foundation, Constitution, 2010, available at http://www.ifrs. org/NR/rdonlyres/0B820728-7F10-4877-8068-7B65D2A3058B/0/ConstitutionDec2010.pdf, para. 2. 
been called International Financial Reporting Standards (IFRS). As the IASB adopted, and continues to update, the IAS, global accounting standards are frequently referred to as the IAS/IFRS.

Founded in 1977 and based in New York City, the International Federation of Accountants' (IFAC) is a private international organization that establishes standards for auditing. Over the past 30 years, IFAC's membership has grown, form the 63 members at the beginning, to now include 155 members ${ }^{39}$. According to IFAC Constitution, the mission of the IFAC is to "serve the public interest"; in particular, it aims at strengthening the accountancy profession in several ways: establishing and promoting adherence to high quality professional standards and furthering the international convergence of such standards ${ }^{40}$. Four IFAC'S committees are charged with a standard setting function: the International Auditing and Assurance Standards Board (IAASB), the International Accounting Education Standards Board (IAESB), the International Ethics Standards Board for Accountants (IESBA) and the International Public Sector Accounting Standards Board (IPSASB), which establish standards, respectively, for auditing, for the accountancy education, for international ethics codes for the accountants, and on the accounting and financial reporting needs of national, regional and local governments ${ }^{41}$.

39 Si v. http://www.ifac.org/History/. For a comment, see A. Loft et al., "In pursuit of global regulation: Changing governance and accountability structures at the International Federation of Accountants (IFAC)", in Accounting, Auditing \& Accountability Journal, Vol. 19, n. 3, 2006, p. 428 ss.

40 See IFAC Constitution, 2012, available at http://www.ifac.org/sites/default/files/callouts/IFAC\%20Constitution.pdf, para. 1.4.

41 See http://www.ifac.org/auditing-assurance, http://www.ifac.org/education; http://www.ifac.org/ethics and http://www.ifac.org/public-sector, respectively.
As IAS/IFRS have been spreading steadily, being recognized as binding in several jurisdictions ${ }^{42}$, the IASB is considered to be a leading example of global private regulation. IFAC's standards (and more specifically its committee IAASB's ones), despite being recognized among the FSB's twelve 'key' standards for financial stability (Section III.A), are less famous.

One significant difference between the two organizations lies in their composition. The IFAC is made up of national organizations representatives of the accountancy profession. It is at the same time the organism representing accountants professionals worldwide and the standard setter for auditing. There might be a potential conflict between the role of international standard setter serving the public interest with the function of representing and promoting the global accounting profession ${ }^{43}$.

Until 2001, the membership of the IFAC and IASC was tightly connected: all members of the first organization were also members of the second one $^{44}$. When the IASC was reorganized as IASB, the composition of the organization changed dramatically: no correspondence with IFAC's membership was provided for, and the aim of representing in the new organizations' four bodies (the IFRS Foundation, the IASB, the IFRS Advisory Council and the IFRS Interpretation Committee)

42 See the survey from Deloitte, Use of Ifrs by jurisdictions, available at http://www.iasplus.com/country/useias.htm.

43 See A. Loft et al., "In pursuit of global regulation", at 442.

44 See IASC Strategy Working Party, Shaping IASC for the Future, Discussion Paper, December 1998, available at http://www.iasplus.com/ resource/ref.htm, at 43. 
all the stakeholders involved in accounting practices (auditors, preparers, users, academics) was clearly stated ${ }^{45}$. Notwithstanding the many provisions of the IFRS Foundation Constitution aimed at ensuring a balanced representation of all the interests involved, some data suggest that the 2001 reform of IASB composition risks substituting the influence of accounting professionals on the organization with the big auditing multinationals' control over it ${ }^{46}$.

\section{E. Summing Up}

A number of different entities intervene in the global financial architecture. They constitute different models of global administration: international, transnational, private. The FSB connects and coordinates all these bodies, working as link among the standard setters (transnational and private) and the G20.

Even though the G20 is playing an increasingly significant role, the standard setting process is still taking place within the transnational regulatory networks, such as the Basel Committee and the Iosco, and within private organizations, such as the IASB and the IFAC. Moreover, the FSB itself a network, bringing together international bodies, transgovernmental networks and national authorities- is setting its own standards, a function that its predecessor, the FSF, did not have. Hence, in the global financial architecture the G20 is giving its political endorsement to

45 See IFRS Foundation Constitution, par. 7, 25 and 27.

46 See Sebastian Botzem, "Transnational Expert-driven Standardisation - Accountancy Governance from a Professional Point of View", in Jean-Christophe Graz and Andreas Nölke (eds.), Transnational Private Governance and its Limits, London, Routledge, 2007, p. 44 ss., at 54 regulatory options which are first elaborated in the Board and to standard which are drafted by transnational networks.

\section{THE STANDARDS AND THE STANDARD-SETTING PROCEDURE}

Global standards cover many areas of financial regulation and are drafted in different ways (some are broader and other more specific). A good starting point for their examination is the FSB Compendium of financial standards, even though the effectiveness of global regulation is strictly linked with the implementation of more specific rules, such as the Basel capital accord, the Iosco Code of conduct for Credit rating agencies and the FSB recommendations about derivatives and systemically important financial institutions (SIFI).

\section{A. The 12 'Key' Standards of the FSB Compendium}

Already at the end of the 90s, the FSF started compiling a "Compendium of Standards", bringing together all the financial and economic standards, internationally recognized as “important for sound, stable and well functioning financial systems", established by the members of the FSF. The Compendium has been later on endorsed by the FSF successor, the FSB.

The FSB's initiative focuses on the twelve "key standards" of the Compendium that are deemed essential for sound financial systems. The 'key' standards correspond to an equal number of subject areas that are, in turn, re-grouped into 
three macro areas. The "Macroeconomic Policy and Data Transparency" macro-area includes monetary and financial policy transparency, fiscal transparency and data dissemination. "Financial Regulation and Supervision" embraces banking, insurance and securities supervision. The "Institutional and Market Infrastructure" macro-area covers crisis resolution and deposit insurance, insolvency, corporate governance, accounting, auditing, payment and settlement and market integrity.

Among the most relevant key standards are the Basel Core Principles for effective Banking supervision (CPBS), the Iosco's Objectives and Principles of Securities Regulation, the IASB'S IAS/IFRS and the International Standards on Auditing established by the IFAC'S IAASB ${ }^{47}$.

The updating process has continued in the last years, with eighty new standards added in the last five years. Hence, the Compendium helps identifying the most relevant global financial standards ${ }^{48}$.

\section{B. The Basel Capital Accord}

Regulating capital has long been considered one of the main instruments to control financial stability. The global financial crisis of 20082010 showed that the level of capital was insufficient vis-à-vis the risks financial institutions were taking.

47 See http://www.financialstabilityboard.org/cos/key_standards.htm .

48 See http://www.financialstabilityboard.org/list/fsb_cos_subject_area/ index.htm.
The Basel Committee's most known standard, the Basel II, was published in June 2004, after an extensive consultative process, and was intended to substitute the 1988 Basle Capital Ac$\operatorname{cord}^{49}$. Basel II allows banks to choose between two methodologies for calculating the capital requirements for credit risks: the 'standardized' approach (according to which risk weights - and, consequently, the capital requirements that a bank has to respect - depend on the issuer's rating), and the 'internal ratings-based' approach (IRB, according to which qualifying banks can use their own estimates to quantify their exposure).

Basel II has been criticized for a number of reasons, such as its pro-cyclical effect ${ }^{50}$ and the two methods set forth by the accord. The standardized approach might lead to wrong risk weights, a possibility which appears even more likely after the agencies' poor performance during the crisis $^{51}$. Opinions about the IRB approach are more nuanced ${ }^{52}$.

49 See http://www.bis.org/publ/bcbsca.htm.

50 See The High Level Group on Financial Supervision in the EU, Report (so called De Larosière Report), 25 February 2009, available at http://ec.europa.eu/internal_market/finances/committees/index_ en.htm\#delarosierereport, at 17-21; Group of Thirty, Financial Reform: A Framework for Financial Stability, 2009 http://www.group30.org/ pubs/pub_1460.htm, at 12-4; FSF, Report of the Financial Stability Forum on Enhancing Market and Institutional Resilience, 7 April 2008, available at http://www.fsforum.org/list/fsf publications/tid_110/index. htm, at 15.

51 See De Larosière Report, at 16; C. Calomiris, "Prudential Bank Regulation: What's Broke and How To Fix It”, Working Paper, April 2009, available at http://www.cmc.edu/somc/charles_calomiris_2_042009. pdf, at 5 .

52 For an overall critique, see Daniel Tarullo, Banking on Basel, at 177 189 and 265-270; for a more nuanced approach, see De Larosière Report, at 16, claiming that internal risk models "may pass the test for normal conditions", but they were "clearly based on too short statistical horizons and this proved inadequate for the recent exceptional circumstances". 
Following the G20's and the FSB's recommendations, the Basel Committee reviewed the global standard for capital requirements, which was

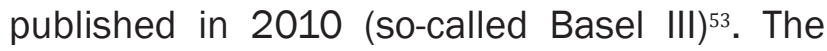
changes in the accord have two main purposes: forcing banks to have more and higher-quality capital, and the setting of 'dynamic' capital requirements (in order to avoid pro-cyclicity) ${ }^{54}$. These two purposes are pursued raising banks' common equity at $7 \%$ of risk-weighted assets, including a $2.5 \%$ capital conservation buffer, and a countercyclical buffer.

According to commentators, Basel III will increase steadily banks' capital requirements, contributing to their stability ${ }^{55}$. Yet, the two controversial risk-weighting methods (standard and IRB) were not changed; a choice which raises criticism $^{56}$. In more general terms, the negative impact of the new capital rules on growth, especially in the context of the European sovereign debt crisis, is highly problematic ${ }^{57}$.

1. 53 See BCBS, Basel III: International framework for liquidity risk measurement, standards and monitoring, 16 December 2010, available at http://www.bis.org/publ/bcbs188.htm. A revised version has been published in June 2011: see BCBS, Basel III: International framework for liquidity risk measurement, standards and monitoring. Revised version, 1 June 2011, available at http://www.bis.org/publ/bcbs189. $\mathrm{htm}$.

54 See Jaime Caruana, Regulatory reform: remaining challenges, 7 July 2011, available at http://www.bis.org/speeches/sp110711.htm .

55 See Adrian Blundell-Wignall and Paul Atkinson, Thinking Beyond Basel III: Necessary Solutions for Capital and Liquidity, May 2010, in OECD Journal: Financial Market Trends, 2010, disponibile anche all'indirizzo www.oecd.org/dataoecd/42/58/45314422.pdf, at 13-4.

56 See Alan Blinder, Two cheers for the New Bank Capital Standards, in Wall Street Journal, 30 Septemeber 2010; Adrian Blundell-Wignall and Paul Atkinson, Thinking Beyond Basel III, p. 16-7 e 21.

57 Si v. Douglas J. Elliott, Basel III, the Banks and the Economy, 23 July 2010, The Brooking Institution paper, available at http://www.brookings.edu/papers/2010/0726_basel_elliott.aspx, p. 1.
As mentioned above, Basel II was approved following a due process that marked a move from the previous secrecy of the Committee. It involved the publication of three consultative draft, each followed by a period in which interested parties could send their comments. Participation in the process was massive, with more than two hundred comment letters for each consultative document ${ }^{58}$. Yet, BcBs's due process for the approval of capital rules encountered two limits: first, stakeholders involved were mostly banks and financial institutions, with little or no input from consumers and academics ${ }^{59}$; second, participation was granted by the Committee on a case by case basis, with no general rule limiting its discretion for the future being set forth ${ }^{60}$.

Legal scholars suggested procedural rights granted in Basel II standard setting procedure enhanced the accountability of the network ${ }^{61}$. Yet, a different interpretation has been suggested: that it might have led to the global regulator's capture by the banks ${ }^{62}$.

When Basel III was approved, only one exposure draft for public comments was published ${ }^{63}$, while the final document was released after one year

58 See http://www.bis.org/bcbs/cacomments.htm .

59 See Michael S. Barr and Geoffrey P. Miller, "Global Administrative Law: the View from Basel", p. 24.

60 See Stefano Battini, "Introduzione”, in Id. (ed.), La regolazione globale dei mercati finanziari, Giuffrè, 2007, p. 1 ss., at 11.

61 See Michael S. Barr and Geoffrey P. Miller, "Global Administrative Law: the View from Basel”, p. 24.

62 Duncan R. Wood, Governing Global Banking, at 150.

63 See BCBS, Consultative proposals to strengthen the resilience of the banking sector announced by the Basel Committee, 17 December 2009, available at http://www.bis.org/press/p091217.htm. 
(a much shorter period than the five years necessary to finalize Basel II). Instead of three notice and comment rounds, only one was used by the Committee. Participation was widespread, with more than two-hundred comment letters being sent to the Committee ${ }^{64}$. Again, participants were mostly banks and financial institutions.

Global rules for capital requirements are highly controversial. They seem to be a step in the direction of building more stable banks; yet, the risk-weighting methods underlying the accord showed some serious flaws which were not solved. From the point of view of the standard setting procedure which were followed, the Committee's experience suggest that notice and comment used at the global level must be carefully scrutinized, in order for it to effectively lead to both stronger accountability and efficacy, and not to result in a 'regulatory capture'.

\section{The Iosco Code of Conduct Fundamentals for Credit Rating Agencies}

Credit rating agencies such as Standard \& Poor's, Moody's and Fitch - private firms that evaluate an issuer's credit-worthiness- became famous during the global financial crisis, due to the continuous downgrading of complex structured credit products to which, a little time before, they had assigned extremely high ratings ${ }^{65}$.

CRAS' poor performance during the crisis is strict-

64 See Comments received on the consultative documents "Strengthening the resilience of the banking sector" and "International framework for liquidity risk measurement, standards and monitoring", April 2010, available at http://www.bis.org/publ/bcbs165/cacomments.htm. ly connected to the conflict of interest inherent in their activity, as CRAS are paid by the issuer they evaluate ${ }^{66}$. The risk of conflict is even higher in the area of derivatives, now counting for the majority of the CRAS' revenue ${ }^{67}$. Moreover, in some cases misjudgements resulted from the use of poor statistical methodologies ${ }^{68}$.

When the crisis unfolded, a global standard for CRAS was already in place, as the Iosco published its Code of Conduct Fundamentals for Credit Rating Agencies in $2004^{69}$.

The purpose of the Iosco Code was the one of to promoting investor protection ${ }^{70}$. To this end, it focused on safeguarding the integrity and the quality of the rating process, as well as on safeguarding the independence of the agencies and avoiding conflicts of interest.

According to the Code, a CRA should publish its rating methodology and rating should reflect all the information known, and believed to be relevant, by the $\mathrm{CRA}^{71}$.

66 See, ex multis, Wilem H. Buiter, "Lessons from the 2007 Financial Crisis”, CESR Policy Insight n. 18, December 2007, available at www. cepr.org, at 4.

67 See John C. Coffee, "The Mortgage Meltdown And Gatekeeper Failure", in New York Law Journal, September 20, 2007, 5, and Charles A. Goodhart, "How, if at all, should CRAs be regulated?", in Id., The regulatory response to the financial crisis, Edward Elgar Publishing, 2009, 113 et seq., at 121.

68 See CGFS, Ratings in structured finance: what went wrong and what can be done to address shortcomings?, CGFS Publications N. 32, July 2008, available at http://www.bis.org/publ/cgfs32.htm, at 5.

69 See IOSCO, Code Of Conduct Fundamentals For Credit Rating Agencies, December 2004, IOSCOPD180.

70 See IOSCO CRA Code, at 3.

71 IOSCO CRA Code, at para. 1.1. and 1.4. 
Some relevant provision focus on ancillary services, one of the most controversial aspects of CRAS activity as they can result in additional conflicts of interests: for example, the agencies could advice a client on how to structure a security in order to obtain the best rating and subsequently rate the security designed according to their own suggestions) $)^{72}$. The first version of the Code did not forbid them; yet, it asked the agency to "separate, operationally and legally, its credit rating business and $L$ analysts from any other businesses of the CRA, including consulting businesses that may present a conflict of interest". Moreover, the CRA "should ensure that ancillary business operations which do not necessarily present conflicts of interest with the CRA's rating business have in place procedures and mechanisms designed to minimize the likelihood that conflicts of interest will arise" ${ }^{73}$.

The Iosco Code is a voluntary standard. According to it, Iosco members expected CRAS to give the Code full effect ${ }^{74}$.

In 2008, after the crisis unfolded, revealing a number of criticisms in CRAS conduct, the IOSco Code was revised ${ }^{75}$. Not surprisingly, main changes concern ratings for financial structured products. First, the Code now asks CRAS to differentiate ratings of structured financial pro-

72 See, Wilem H. Buiter, "Lessons from the 2007 Financial Crisis", at 4.

73 IOSCO CRA Code, at para. 2.5.

$74 \quad$ IOSCO CRA Code, at at 2.

75 IOSCO, The Role of Credit Rating Agencies in Structured Finance Markets - Final Report, May 2008, Annex A, available at http://www. iosco.org/library/pubdocs/pdf/IOSCOPD270.pdf . ducts from traditional corporate bond ratings ${ }^{76}$. Second, taking into account evidence of poor methodologies used by the CRAS in evaluating derivatives, a new provision requires the agencies to refrain from issuing a credit rating, "in cases where the complexity or structure of a new type of structured product or the lack of robust data about the assets underlying the structured product raise serious questions as to whether the CRA can determine a credible credit rating for the security" 77 . No prohibition of providing ancillary services is set forth; yet, according to principle 1.14-1, a CRA "should prohibit its analysts from making proposals or recommendations regarding the design of structured finance products that a cRA rates".

The revision process proves the Iosco itself became aware of substantial gaps in its own Code. Yet, whether these amendments made the global standard for CRAS a more efficient regulation is an open question, partly dependent on the new model of implementation of these standard in domestic jurisdictions (see Section IV.B.).

\section{The FSB Recommendations}

As mentioned above, the FSB moved from the mere role of coordinator of other standard setters' rules played by its predecessor, the FSF, to establishing itself guidelines and recommendations. Examples include the Principles for Sound Compensation Practices $(\mathrm{PSCP})^{78}$, followed by

\footnotetext{
76 Ibidem, principle 3.5. e.

77 Ibidem, principle 1.7-3.

78 FSB, Principles for Sound Compensation Practices, 2 April 2009
} 
more specific Implementation Standards in the same area ${ }^{79}$; and the sets of recommendations about over the counter (отс) derivatives ${ }^{80}$ and systemically significant financial institutions (SIFI) ${ }^{81}$.

The Principles and Standards for compensation practices were approved in 2009, when the pressure for reform, shortly after the collapse of Lehman Brothers, was higher. The FSB efforts for effective action are evident in the formula used: a set of principles followed shortly by standards aimed at specifying the most relevant provisions of the principles themselves.

In the area of derivatives and SIF, the type of rules drafted by the Board enact a much different model of interaction between global and domestic regulation. As the then FSB President, Mario Draghi, put it ${ }^{82}$, in the area of derivatives and SIFI the Board's recommendation do not suggest ex ante harmonization; on the contrary, they aim at fostering convergence when national disciplines have already been adopted.

In two areas generally considered to be crucial for the success of financial reform -as it is well known, derivatives were a key factor in the unfolding of the crisis of 2008, while the consequences coming from the collapse of Lehmann Brothers raised the attention on the problem of

79 Si v. FSB Principles for Sound Compensation Practices. Implementation Standards, 25 September 2009.

80 FSB, Implementing OTC Derivatives Market Reforms, 25 October 2010.

81 FSB, Reducing the moral hazard posed by systemically important financial institutions, 20 October 2010.

82 See the interview to Mario Draghi, La spinta di Draghi alla regolamentazione dei CDS, in IISole24Ore, 8 March 2010. the so-called "too big to fail" institutions-, global rules leave more space to national regulatory autonomy.

\section{E. Summing Up}

Global financial standards are a very diverse set of rules. They can be drafted as broad principles (such as the BCBs Core principles for banking supervision and the Iosco Objectives and Principles for securities supervision, both among the twelve key standards of the Compendium; but also the FSB Principles for sound compensation practices), or more specific rules (Basel Capital accords on capital requirements are a case in point). Moreover, they can also vary from the point of view of their impact on national regulatory autonomy: if most of them aim at fostering ex ante harmonization, some (such as the FSB Recommendations for derivatives and SIFI) are intended to compel convergence in the implementation of national regulations.

Also the efficacy of global rules varies. Basel III has been welcomed as a powerful effort to increase banks' stability; yet, it leaves room for criticism. Moreover, reforms in the area of capital requirements and CRAS have been matched by weaker rules in the equally, if not more, relevant areas of derivatives and SIFIS. This imbalance can stem from the timing of reform, as initiatives approved shortly after the spread of the crisis were less affected by the pressure of financial lobbies ${ }^{83}$. 2009. 
The global financial standard setting process also shows the potential shortcomings of global regulators' due process. In areas different from banking, the standard setting procedure is previously determined in details, and involves a third party assessment on the effective implementation of due process by the regulator: IASB'S and IFAC's due process are two cases in point ${ }^{84}$. The Basel Committee's standard setting procedure looks more problematic: being granted by the Committee on a case by case basis, and involving mostly banks and financial institutions, a risk of regulatory capture is higher.

\section{THE IMPLEMENTATION: BETWEEN HARD AND SOFT LAW}

Compliance with global financial standards is generally voluntary. National authorities may choose to implement global rules, or not, according to the standard setting bodies' expertise ${ }^{85}$ and capacity of persuasion ${ }^{86}$. But things are not so simple. According to some commentators, international organisations' methods to improve implementation of global financial standards "make their adoption essentially mandatory" 87. Slaughter reminds us that transnational regulators' soft law, such as codes of best practices

84 I analyzed the point in further details elsewhere: see Maurizia De Bellis, La regolazione dei mercati finanziari, Milano, Giuffrè, 2012.

Dieter KERWER, "Standardising as Governance: the Case of Credit Rating Agencies", in A. Heritier (ed.), Common Goods: Reinventing European and International Governance, Rowman \& Littlefield Publishers, Lanham, UK, 2002.

86

Anne-Marie Slaughter, A New World Order, at 213

87

Rober P. Delonis. International financial standards and codes, p. 563. and international guidance, can have a "hard impact"88.

In some case, global standards made the transition from soft to hard law also from a formal point of view, being incorporated in binding acts. In other cases, the legal impact global standards have on domestic legal orders is improved through mechanisms less official but sometimes almost equally effective. International financial institutions, namely the IMF and the World Bank, assess States' compliance with global financial standards. More recently, the FSB developed new tools with the aim of strengthening the implementation of financial standards.

\section{A. The Incorporation in Binding Acts}

As mentioned above, standards drafted within transnational regulatory networks are later on implemented by the domestic authorities taking part in TRN. This model of implementation was used already with the Basel capital accord of $1988^{89}$, and is still used for most BCBS' and Iosco's standards.

Yet, things are changing. While in the US, Basel II was implemented through acts of rulemaking of the competent financial authorities ${ }^{90}$, in the

88 Anne-Marie Slaughter, A New World Order, p. 224

89 Si v. United States General Accounting Office (US GAO), International Banking: Implementation of Risk-based Capital Adequacy Standards, GAO/NSIAD-91-80, available at http://archive.gao.gov/d21t9/143022. pdf, pp. 2 e 13

90

See also Pierre-Hughes Verdier, "U.S. Implementation of Basel II: Lessons for Informal International Law-Making”, 30 June 2011, available at http://papers.ssrn.com/sol3/papers.cfm?abstract_id=1879391 and Richard J. Herring, "The Rocky Road to Implementation of Basel II in the United States", in Atlantic Economic Journal, 2007, vol. 35, p. 411 ss 
EU Basel II was incorporated in the Capital Requirements Directive ${ }^{91}$. Also the EU CRAS Regulation -already in its first version-draws widely upon ısco Code provisions ${ }^{92}$.

Hence, the model of the implementation through acts of the national regulatory authorities has been abandoned is often substituted by the formal incorporation of voluntary standards in binding legal acts

Two features can be pointed out. On the one hand, incorporation of global standards within binding acts is less and less an episodic choice, and appears to be the preferential method of implementation when standards perceived as crucial for financial stability come into the picture. On the other hand, under this approach, enforcement rests in the hands of national authorities: thus, the effectiveness of global rules will depend on the type of enforcement national legal systems will provide for.

This trend can also been explained on the basis of EU institutional complexity, and on the lack until recently- of EU financial regulatory authorities. The establishment, after the crisis, of a new European financial architecture could lead to a different result. Recent data seem to go in this

91 Directive 2006/48/EC of the European Parliament and of the Council of 14 June 2006 relating to the taking up and pursuit of the business of credit institutions, and Directive 2006/49/EC of the European Parliament and of the Council of 14 June 2006 on the capital adequacy of investment firms and credit institutions, in OJ L 177, June 30 2006, at 1 et seq.

92 See Regulation (EC) No 1060/2009 of the European Parliament and of the Council of 16 September 2009 on credit rating agencies. For a comment, see Fabian Amtenbrink and Jakob De Haan, "Regulating Credit Ratings in the European Union: A Critical First Assessment of Regulation 1060/2009 on Credit Rating Agencies", in Common Market Law Review, 2009, p. 1915 ss. direction: the newly established European Banking Authority (EBA) has partially implemented Basel III without waiting for the CRD revision process to be completed ${ }^{93}$. The implementation of global standards through acts of the European supervisory authorities - similar to the model currently used in the US- could expand in the EU context as well.

\section{B. The Financial Sector Assessment Pro- gram (FSAP) and the Reports on the Ob- servance of Standards and Codes (ROSCS)}

Since the end of the 90s, the IMF and the World Bank started checking States' compliance with the standards through the Reports on the Observance of Standards and Codes (Roscs), part of the Financial Sector Assessment Program $(\text { FSAP })^{94}$. These are reports on countries' degree of compliance with some global financial standards, wholly coinciding with the Compendium twelve Key Standards ${ }^{95}$, prepared by the IMF's or the World Bank's staff at the request of the State concerned.

During the last decade, the IMF and the World Bank, as well as the FSF, have all placed a notable emphasis on the importance on these as-

93 See EBA, Recommendation on the creation and supervisory oversight of temporary capital buffers to restore market confidence, EBA/ REC/2011/1, 8 December 2011, par. 2.

94 See IMF-WORLD BANK, International Standards: Strengthening Surveillance, Domestic Institutions, and International Markets, 5 March 2003, available at http://www.worldbank.org/ifa/intlstandards.pdf, at 3.

95 That standards indicated as the parameter for assessment procedures correspond to the Key Standards does not follow from the explicit use of the cross-reference technique: a further list is then drawn up which does wholly correspond to that of the 12 Key Standards. 
sessment instruments, leading to the completion of more than a thousand reports by 2008 (before the subprime crisis started fully showing its effects) ${ }^{96}$.

After the crisis, these instruments have been widely criticized. The US case, where the crisis originated and which did not undergo any FSAP or Rosc, suggests that powerful countries such as the US could simply ignore such instruments ${ }^{97}$. This is why a reform of the FSAP, making them mandatory, has been suggested. Currently, FSB members committed to undergo FSAPS, while these review are still voluntary for the jurisdictions not represented in the Board ${ }^{98}$.

\section{The Peer Reviews}

The FSB has recently launched the "Strengthening Adherence to International Standards" project, which aims at fostering the implementation of standards ${ }^{99}$. The first tool introduced for this purpose is the use of peer-reviews. Opposite to the Roscs and FSAPS, peer-reviews do not check the compliance with the twelve key standards of

96 See FSF, Ongoing and Recent Work Relevant to Sound Financial Systems, 15 September 2008, available at www.financialstabilityboard.org/ publications/on_0809.pdf, at 18.

97 See W. Dobson, Delivering Change. Together, in What G20 leaders must do to stabilise our economy and fix the financial system, ed. by B. Eichengreen e R. Baldwin, available at http://www.voxeu.org/reports/ G20_Summit.pdf, p. 45 ss., at 46.

98 See FSB, Progress since the Washington Summit in the Implementation of the G20 Recommendations for Strengthening Financial Stability, cit., p. 2.

99 See FSB, Improving financial regulation - Report by the FSB to G20 Leaders, 25 September 2009, at 12; FSB, Framework for Strengthening Adherence to International Standards, 9 January 2010; Press Release, FSB launches initiative to promote global adherence to cooperation and information exchange standards, 10 March 2010. the Compendium; with the aim of avoiding duplication with the IFIS reports, the FSB will select the standard according to which compliance will be reviewed on a case by case basis ${ }^{100}$. Until now, peer reviews on compliance with FSB Principles on compensation and with the International Association of Deposit Insurers (IADI) Principles on deposit insurance systems have been conducted $^{101}$. Also country specific peer reviews (concerning Mexico, Italy and Spain) have been undertaken ${ }^{102}$.

\section{Summing Up}

Compliance with global financial standards is high. This does not always stem from the model of implementation the literature about TRNS has considered to be the most common: the one of domestic authorities voluntarily applying the standards within their domestic legal orders. On the contrary, incorporation in binding acts through the legislative process can occur. Yet, this can also depend on different institutional patterns, such as the recent evolution within the EU, after the establishment of the new Eu-

100 FSB, Framework for Strengthening Adherence to International Standards, at 2.

101 Si v. FSB, Thematic Review on Compensation. Peer Review Report, 30 March 2010, available at http://www.financialstabilityboard.org/ publications/r_100330a.pdf; FSB, FSB launches second peer review on compensation practices and invites feedback from stakeholders, 18 March 2011, available at http://www.financialstabilityboard.org/press/ pr_110518.pdf; FSB, FSB launches peer review on deposit insurance systems and invites feedback from stakeholders, 1 July 2011, available at http://www.financialstabilityboard.org/press/pr_110701.pdf.

102 See FSB, Country Review of Mexico. Peer Review Report, 23 September 2010, available at http://www.financialstabilityboard.org/ publications/r_100927.pdf; FSB, Country Review of Italy. Peer Review Report, 27 January 2011, available at http://www.financialstabilityboard.org/publications/r_110207b.pdf; FSB, Country Review of Spain. Peer Review Report, 27 January 2011, available at http://www.financialstabilityboard.org/publications/r_110207a.pdf. 
ropean financial authorities, show. No model of implementation is prevailing on the other, and the distinguishing lines are blurring.

The implementation of the standards is crucial for their effectiveness. Yet, compliance is a precondition for this purpose, but it does not, per se, guarantee it. The new mechanisms recently established under the aegis of the FSB still focus on compliance, and no remedy is provided if a national authority does not enforce a domestic law implementing a global standard.

\section{CONCLUDING REMARKS}

Different types of authorities take part in the global financial architecture: international, transnational, and national; public and private. The FSB, strengthened in 2009, aims at coordinating the work of all these bodies. Yet, not all these actors play the same functions: the G20 aims at setting the agenda of reform and gives its political endorsement to technical bodies; the IMF and the World Bank, through the FSAP and Roscs, work as standard enforcers, not as standard setters. The standard setting process itself is still, even after the crisis, in the hands of transnational networks. Moreover, the FSB - a network itself, even if made up of more heterogeneous component than the BCBS and the Iosco, transgovernmental networks which take part in the FSB and which are made up of national regulatory authorities in the banking and securities areas, respectively - is, contrary to its predecessor, also a standard setter.

Global financial standards aim at regulating a number of different aspects relevant for finan- cial stability. Notwithstanding their high number, though, their capacity to prevent a new crisis is questionable. After five years since the collapse of Lehman Brothers, reforms are still half way, especially in the area of derivatives and systemically important financial institutions.

Both transgovernmental and private standard setters have improved their standard setting procedure over time. Such process has at first been regarded as a positive trend, leading to stronger accountability of the regulator involved. Yet, some examples - such as the drafting of Basel II- show that principles and procedures coming from national administrative law traditions - such as participation and notice and comment- can result, at the global level, in a risk of regulatory capture even higher than the one well known at the national level. GaL instruments need to be attentively tailored, in order to guarantee the balanced representation of all the interests at stake and, hence, to prevent regulatory capture. Otherwise, their potential positive effect on both the accountability of global regulators and the efficacy of regulation is impaired.

A second key evolution in the functioning of the networks lies in the changing of the implementation models of the standards. The direct implementation of standards through acts of national authorities, albeit still in place, is not the rule anymore. When standards perceived as particularly relevant are involved, they are often incorporated in binding acts, such as EU directive or regulations. This shows the uneasiness with which EU institutions look at standards drafted by technocratic bodies. The approval of a 
directive or a regulation incorporating the global standard aims at making this voluntary rule pass through the ordinary process of approval. Yet, this does not fully improve legitimacy, as the content of the global rule has already been established. Notice and comment procedures -if structured in a way that all the interests involved are represented-taking place at the moment of the drafting of the standard can be more effective for this purpose.

On the other hand, the various mechanisms used to assess compliance with standards show efforts to increase the effectiveness of global regulation. Yet, the lack of control on the enforcement of the standards is worrisome.

\section{Bibliography}

Amtenbrink, Fabian and De Haan, Jakob, "Regulating Credit Ratings in the European Union: A Critical First Assessment of Regulation 1060/2009 on Credit Rating Agencies", in Common Market Law Review, 2009.

Arner, Douglas W. and Taylor, Michael W., "The Global Financial Crisis and the Financial Stability Board: Hardening the Soft Law of International Financial Regulation?", 2009, AllFL Working Paper No. 6, available at http:// ssrn.com/abstract=1427084,

Bank for International Settlements, Comments received on the consultative documents "Strengthening the resilience of the banking sector" and "International framework for liquidity risk measurement, standards and monitoring", April 2010, available at http:// www.bis.org/publ/bcbs165/cacomments. htm.

Barr, Michael S. and Miller, Geoffrey P., "Global Administrative Law: the View from Basel", in European Journal of International Law, 2006, Vol. 17, n. 1.

Battini, Stefano, "Introduzione”, in Id. (ed.), La regolazione globale dei mercati finanziari, Giuffrè, 2007.

BCBS, Basel Committee Broadens its Membership, Press Release, 10 June 2009, available at http://www.bis.org/press/p090610.htm.

BCBS, Basel III: International framework for liquidity risk measurement, standards and monitoring. Revised version, 1 June 2011, available at http://www.bis.org/publ/bcbs189. htm.

BCBS, consultative proposals to strengthen the resilience of the banking sector announced by the basel committee, 17 December 2009, available at http://www.bis.org/ press/p091217.htm.

Blinder, Alan, "Two cheers for the New Bank Capital Standards", in Wall Street Journal, 30 September 2010.

Blundell-Wignall, Adrian and Atkinson, Paul, Thinking beyond Basel III: Necessary Solutions for Capital and Liquidity, May 2010, in OECD Journal: Financial Market Trends, 2010, disponibile anche all'indirizzo www. oecd.org/dataoecd/42/58/45314422.pdf 
Bogdandy, Armin von, "Legitimacy of International Economic Governance: Interpretative Approaches to WTO law and the Prospects of its Proceduralization", in Stefan Griller (ed.), International Economic Governance and Non-Economic Concerns - New Challenges for the International Legal Order, Wien-New York, Springer, 2003.

Botzem, Sebastian, "Transnational Expert-driven Standardisation - Accountancy Governance from a Professional Point of View", in JeanChristophe Graz and Andreas Nölke (eds.), Transnational Private Governance and its Limits, London, Routledge, 2007.

Bradlow D. D. and Hunter, D. B. (eds.), International Institutions and International Law, Alphen - The Netherlands, Wolters Kluwer, 2010.

Braithwaite, John and Drahos, Peter P., Global Business Regulation, Cambridge, Cambridge University Press, 2000.

Buiter, Wilem H., "Lessons from the 2007 Financial Crisis", CESR Policy Insight n. 18, December 2007, available at www.cepr.org.

Buthe, Tim e Mattli, Walter, The New Global Rulers. The Privatization of Regulation in the World Economy, Princeton e Oxford, Princeton University Press, 2011.

Calomiris, C., "Prudential Bank Regulation: What's Broke and How to Fix It", Working Paper, April 2009, available at http://www.cmc. edu/somc/charles_calomiris_2_042009. pdf.
Caruana, Jaime, Regulatory reform: remaining challenges, 7 July 2011, available at http:// www.bis.org/speeches/sp110711.htm .

Cassese, Sabino et al., (eds.), Global Administrative Law: Cases, Materials, Issues, second edition 2008, available at www.iilj.org/ GAL/GALCasebook.asp.

Cassese, Sabino, "A Global Due Process of Law", in Anthony Gordon et al. (eds.), Values in Global Administrative Law, Oxford, Hart Publishing, 2011.

CGFS, Ratings in structured finance: what went wrong and what can be done to address shortcomings?, CGFS Publications n. 32, July 2008 , available at http://www.bis.org/ publ/cgfs32.htm.

Coffee, John C., "The Mortgage Meltdown and Gatekeeper Failure", in New York Law Journal, September 20, 2007, 5.

De Bellis, Maurizia, La regolazione dei mercati finanziari, Milano, Giuffrè, 2012.

De Bellis, Maurizia, "EU and Global Private Regulatory Regimes: the Accounting and Auditing Sectors", in Edoardo Chiti and Bernardo G. Mattarella (eds.), Global Administrative Law and EU Administrative Law. Relationships, Legal Issues and Comparison, Springer, 2011.

Della Cananea, Giacinto, "Beyond the State: the Europeanization and Globalization of Procedural Administrative Law", in European Public Law, 2003. 
Deloitte. Use of Ifrs by jurisdictions, available at http://www.iasplus.com/country/useias. htm.

Delonis, Robert P., "International Financial Standards and Codes: Mandatory Regulation without Representation", in New York University Journal of International Law \& Politics, 2004, Vol. 36.

Dobson, W., “Delivering Change. Together”, in B. Eichengreen e R. Baldwin (coord.) What G20 leaders must do to stabilise our economy and fix the financial system, available at http://www.voxeu.org/reports/G20_Summit.pdf

Draghi, Mario, "La spinta di Draghi alla regolamentazione dei CDS", in II Sole 24 Ore, 8 March 2010. Int

EBA, Recommendation on the creation and supervisory oversight of temporary capital buffers to restore market confidence, EBA/ REC/2011/1, 8 December 2011.

Eichengreen, Barry, Toward a New Financial Architecture. A Practical Post-Asia Agenda, Washington D. C., Institute for International Economics, 1999.

Elliott, Douglas J., Basel III, the Banks and the Economy, 23 July 2010, The Brooking Institution paper, available at http://www.brookings.edu/papers/2010/0726_basel_elliott. aspx, p. 1

European Parliament, Directive 2006/48/EC of the European Parliament and of the Council of 14 June 2006, relating to the taking up and pursuit of the business of credit institutions.

European Parliament, Directive 2006/49/EC of the European Parliament and of the Council of 14 June 2006 on the capital adequacy of investment firms and credit institutions, in Official Journal, L 177, June 302006.

FSB, FSB launches peer review on deposit insurance systems and invites feedback from stakeholders, 1 July 2011, available at http://www.financialstabilityboard.org/ press/pr_110701.pdf.

FSB, FSB launches second peer review on compensation practices and invites feedback from stakeholders, 18 March 2011, available at http://www.financialstabilityboard. org/press/pr_110518.pdf.

FSB, Country Review of Italy. Peer Review Report, 27 January 2011, available at http://www. financialstabilityboard.org/publications/ r_110207b.pdf.

FSB, Implementing OTC Derivatives Market Reforms, 25 October 2010.

FSB, Reducing the moral hazard posed by systemically important financial institutions, 20 October 2010.

FSB, Country Review of Mexico. Peer Review Report, 23 September 2010, available at http://www.financialstabilityboard.org/ publications/r_100927.pdf. 
FSB, Thematic Review on Compensation. Peer Review Report, 30 March 2010, available at http://www.financialstabilityboard.org/ publications/r_100330a.pdf.

FSB, Framework for Strengthening Adherence to International Standards, 9 January 2010.

FSB, Financial Stability Board Charter, September 2009, available at http://www.financialstabilityboard.org/publications/r_090925d.pdf .

FSB, Principles for Sound Compensation Practices. Implementation Standards, 25 September 2009.

FSB, Improving financial regulation - Report by the FSB to G20 Leaders, 25 September 2009.

FBS, Press Release, Financial Stability Forum reestablished as the Financial Stability Board, 2 April 2009, available at http://www.financialstabilityboard.org/press/pr_090402b. pdf.

FSB, Principles for Sound Compensation Practices, 2 April 2009.

FSB, Progress since the Washington Summit in the Implementation of the G20 Recommendations for Strengthening Financial Stability

FSF, Report of the Financial Stability Forum on Enhancing Market and Institutional Resilience, 7 April 2008, available at http://www.fsforum. org/list/fsf_publications/tid_110/index.htm.
FSF, Ongoing and Recent Work Relevant to Sound Financial Systems, 15 September 2008, available at $w w w$.financialstabilityboard.org/publications/on_0809.pdf.

G-7, Communiqué of G-7 Finance Ministers and Central Bank Governors, 20 February 1999, available at http://www.g7.utoronto.ca/ finance/fm022099.htm.

G-7, Economic Communiqué: Making a Success of Globalization for the Benefit of All, 28 June 1996, available at http://www.g7.utoronto. ca/summit/1996lyon/communique.html.

G-20, Leaders' Statement, Pittsburgh, 23-4 September 2009, available at http://www. g20.org/Documents/pittsburgh_summit_leaders_statement_250909.pdf.

Germain, Randall D., "Global Financial Governance and the Problem of Inclusion", in Global Governance, 2001, Vol. 7.

Goodhart, Charles A., "How, if at all, should CRAs be regulated?", in The regulatory response to the financial crisis, Edward Elgar Publishing, 2009.

Group of Thirty, Financial Reform: A Framework for Financial Stability, 2009, available at http://www.group30.org/pubs/pub_1460. htm.

Helleiner, Eric, “La riforma della regolamentazione finanziaria internazionale: le cose fatte e quelle da fare", in P. Guerrieri e D. Lombardi (eds.), L'architettura del mondo nuovo, Bologna, Il Mulino, 2010. 
Herring, Richard J., "The Rocky Road to Implementation of Basel II in the United States", in Atlantic Economic Journal, 2007, Vol. 35.

IFAC, Constitution, 2012, available at http:// www.ifac.org/sites/default/files/callouts/IFAC\%20Constitution.pdf.

IFRS Foundation, Constitution, 2010, available at http://www.ifrs.org/NR/ rdonlyres/OB820728-7F10-4877-80687B65D2A3058B/0/ConstitutionDec2010.pdf.

IMF-World Bank, International Standards: Strengthening Surveillance, Domestic Institutions, and International Markets, 5 March 2003, available at http://www.worldbank. org/ifa/intlstandards.pdf.

IOSCO, The Role of Credit Rating Agencies in Structured Finance Markets - Final Report, May 2008, Annex A, available at http:// www.iosco.org/library/pubdocs/pdf/IOSCOPD270.pdf .

IOSCO, Code of Conduct Fundamentals for Credit Rating Agencies, December 2004, IOSCOPD180.

IOSCO, Code of Conduct Fundamentals for Credit Rating Agencies, Consultation Report from the TC Chairmen Task Force on CRAs, October 2004, IOSCOPD173, and Public Comments on Code of Conduct Fundamentals for CRAs, November 2004, IOSCOPD177.

International Accounting Standards Committee, Strategy Working Party, Shaping IASC for the Future, Discussion Paper, December 1998, available at http://www.iasplus.com/ resource/ref.htm.

Kapstein, Ethan B., Governing the Global Economy. International Finance and the State, 1994.

Kerwer, Dieter, "Standardising as Governance: the Case of Credit Rating Agencies", in A. Heritier (ed.), Common Goods: Reinventing European and International Governance, Rowman \& Littlefield Publishers, Lanham, UK, 2002.

Kingsbury, Benedict and Krisch, Nico, (eds.), "Global Governance and Global Administrative Law in the International Legal Order", in European Journal of International Law, 2006, Vol. 17.

Kingsbury, Benedict et al., (eds.), "The Emergence of Global Administrative Law", in Law and Contemporary Problems, 2005, Vol. 68.

Kingsbury, Benedict et al., "Global Governance as Administration - National and Transnational Approaches to Global Administrative Law", in Law \& Contemporary Problems, 2005, Vol. 68, n. 3 - 4.

Kingsbury, Benedict, "Global Administrative Law symposium", in New York University Journal of International Law and Politics, 2005, Vol. 37.

Larosiere, Jackes, De Larosière Report, available at http://ec.europa.eu/inter- 
nal_market/finances/committees/index_ en.htm\#delarosierereport.

Loft, A., et al., "In pursuit of global regulation: Changing governance and accountability structures at the International Federation of Accountants (IFAC)", in Accounting, Auditing \& Accountability Journal, 2006, Vol. 19, n. 3.

Mattli, Walter and Buthe, Tim, "Global Private Governance: Lessons from a National Model of Setting Standards in Accounting", in Law $\&$ Contemporary Problems, 2005, Vol. 68, n. $3-4$.

Miller, Martin, “Deliberative', 'Independent' Technocracy v. Democratic Politics: Will the Globe Echo the EU?", in Law \& Contemporary Problems, 2005, Vol. 68, n. 3 - 4.

Mosley, Layna, "An End to Global Standards and Codes?", in Global Governance, 2009, Vol. 15.

Murden, W., "Banking Supervision and Government Policy: the Role of Regulators in International Financial Reform", in Fordham Finance, Securities and Tax Law Forum, 1999, Vol. 4.

Pan, Eric J., “Challenge of International Cooperation and Institutional Design in Financial Supervision: Beyond Transgovernmental Networks", in Chicago Journal of International Law, 2010, Vol. 11.

Picciotto, Sol, "Networks in International Economic Integration: Fragmented States and the Dilemmas of Neo-Liberalism", in North- western Journal of International Law \& Business, 1997, Vol. 17, n. 2 - 3.

Portes, Richard, "Wasting a Crisis", in Eurointellingence, 8 October 2009.

Raustiala, Kal, "The Architecture of International Cooperation: Transgovernmental Networks and the Future of International Law", in Virginia Journal of International Law, 2002, Vol. 43, n. 1.

Shapiro, Martin, “Deliberative', 'Independent' Technocracy v. Democratic Politics: Will the Globe Echo the EU?", in Law \& Contemporary Problems, 2005, Vol. 68.

Sinclair, Timothy, "The Infrastructure of Global Governance: Quasi-Regulatory Mechanisms and the New Global Finance", in Global Governance, 2001, Vol. 7.

Slaughter, Anne-Marie, "The Real New World Order", in Foreign Affairs, 1997, Vol. 76, n. 5.

Slaughter, Anne-Marie, A New World Order, 2004.

Sommer, A. A., Jr., "Iosco: its Mission and Achievement", in Northwestern Journal of International Law \& Business, 1996 - 1997, Vol. 17.

Stewart, Richard, "Administrative Law in 21st century", in New York Law Review, 2003, Vol. 78.

Stewart, Richard, "U.S. Administrative Law: a Model for Global Administrative Law?", in 
Law \& Contemporary Problems, 2005, Vol. $68, n^{\circ} .3-4$.

Tarullo, Daniel, Banking on Basel. The Future of International Financial Regulation, Washington D.C., Peterson Institute, 2008.

United States General Accounting Office, International Banking: Implementation of Riskbased Capital Adequacy Standards, GAO/ NSIAD-91-80, available at http://archive. gao.gov/d21t9/143022.pdf.

Verdier, Pierre-Hughes, "Transnational Regulatory Networks and Their Limits", in Yale Journal of International Law, 2009, Vol. 34.

Verdier, Pierre-Hughes, “U.S. Implementation of Basel II: Lessons for Informal International Law-Making", 30 June 2011, available at http://papers.ssrn.com/sol3/papers. cfm?abstract_id=1879391

Warning, Michael J., Transnational Public Governance. Networks, Law and Legitimacy, New York, Palgrave, 2009.

Wood, Duncan R., Governing Global Banking. The Basel Committee and the Politics of Financial Globalization, Aldershot, Ashgate Publishing, 2005.

Woods, Ngaire, The Globalizers. The IMF, the World Bank, and Their Borrowers, Ithaca, Cornell University Press, 2006.

Zaring, David, "Informal Procedure, Hard and Soft, in International Administration", in The University of Chicago International Law Jour- nal, 2005, Vol. 5, available at http://ssrn. com/abstract $=692764$.

Zaring, David, "International Institutional Performance in Time of Crisis", in Chicago Journal of International Law, 2010, Vol. 10.

Zaring, David, "International Law by Other Means: The Twilight Existence of International Financial Regulatory Organizations", in Texas International Law Journal, 1998, Vol. 33, n. 2.

Zaring, David, Peer Review As a Metric of Success For Regulatory Networks, Paper presented at the V GAL Seminar, Viterbo, 12-3 giugno 2009, available at http://www.irpa. eu/wp-content/uploads/2011/06/81.pdf.

\section{Páginas web}

http://www.bis.org/bcbs/cacomments.htm .

http://www.bis.org/publ/bcbsca.htm.

http://www.financialstabilityboard.org/cos/ key_standards.htm .

http://www.ifac.org/auditing-assurance,

http://www.ifac.org/education;

http://www.ifac.org/ethics and http://www.ifac. org/public-sector 